\title{
The growing controversy about growth charts: WHO or regional?
}

\author{
Vaman Khadilkar \\ From 7th APPES Biennial Scientific Meeting \\ Nusa Dua, Bali. 14-17 November 2012
}

\begin{abstract}
Introduction
Since production of WHO Multicenter Growth Reference Study (MGRS) growth standards in 2006, many countries have adopted the WHO charts for under five children [1]. In UK, WHO growth charts are used until 4 years [2] and in US only up to 2 years of age. Over-diagnosis of stunting and underweight in Asian children is likely with the use of these standards as Asian children are still thinner and lighter.
\end{abstract}

\section{Growth standard vs. reference}

A growth reference simply describes the growth of a sample of individuals, whereas a standard describes the growth of a 'healthy' population and suggests an aspirational model. WHO growth charts are growth standards. A reference is representative of the existing growth pattern of children and allows us to study the secular trends in height, weight and obesity.

\section{Advantages of WHO growth charts}

WHO growth standards have given a platform to compare growth of under five children across all races and ethnicity against a single standard, thus assessment becomes objective and easy. They show more physiological growth pattern as the children in MGRS study were breast fed and hence leaner, promoting prevention of obesity from a younger age. The MGRS provides an unsurpassed foundation for a growth standard based on healthy children living under conditions that favored the achievement of full genetic potential.

\section{Disadvantages of WHO growth standards}

In developing nations the WHO 2006 standards tend to over-diagnose stunting and wasting. In a nationwide study done by the author on apparently healthy affluent

\footnotetext{
Pediatric Endocrinologist, HCJMRI and Bharati Vldyapeeth Medical College,
} Pune, India

(c) 2013 Khadilkar; licensee BioMed Central Ltd. This is an Open Access article distributed under the terms of the Creative Commons Attribution License (http://creativecommons.org/licenses/by/2.0), which permits unrestricted use, distribution, and reproduction in any medium, provided the original work is properly cited.
Indian children the percentage of stunting was $13.6 \%$ for boys and $11.2 \%$ for girls and that for wasting was $8.5 \%$ for boys vs. $10.4 \%$ for girls [3]. Similar concerns are expressed by authors from other developing countries such as Indonesia [4], and Malawi [5]. In a study done by Kerac $\mathrm{M}$ et al on data from 21 countries it was concluded that use of WHO standards to define wasting results in a greater disease burden, in children under the age of 6 months[6] .

\section{Conclusion}

WHO 2006 growth standards are useful for comparison of growth of children around the world but caution regarding referral for investigations of failure to thrive, changing infant feeding policies and intervention programs based on WHO 2006 standards for the developing part of the world is needed at least for the present time.

\section{Published: 3 October 2013}

\section{References}

1. de Onis Mercedes, et al: WHO Child growth standards. Acta pediatrica 2006, 95(supplement 450).

2. Application of WHO Growth Standards in the UK: Report prepared by the Joint SACN/RCPCH Expert Group on Growth Standards. TSO The Royal College of Paediatrics and Child Health London; 2007.

3. Khadilkar W, Khadilkar AV, Chiplonkar SA: Growth Performance of Affluent Indian Preschool Children: A Comparison with the New WHO Growth Standard. Indian Pediatr 2010, 47:869-872.

4. Julia M: Adoption of the WHO Child Growth Standards to classify stronger indication for nutritional intervention. Food Nutr Bull 2009, 30(3):254-9.

5. Ahmad UN: A randomised controlled trial exploring how new who growth charts influence healthcare workers' clinical decisions and recommendations about exclusive breastfeeding for infants aged $<6$ months. Arch Dis Child 2011, 96:A73, doi:10.1136/adc.2011.212563.170.

6. Marko K, Hannah B, Carl O, McGrath M, Shoham J, Cole TJ, Seal A: Prevalence of wasting among under 6-month-old infants in developing countries and implications of new case definitions using WHO growth standards: a secondary data analysis. Arch Dis Child 2011, 96:1008-1013. Indonesian children under 2 years of age according to nutrition status: 
doi:10.1186/1687-9856-2013-S1-O6

Cite this article as: Khadilkar: The growing controversy about growth

charts: WHO or regional? International Journal of Pediatric Endocrinology

2013 2013(Suppl 1):O6.

Submit your next manuscript to BioMed Central and take full advantage of:

- Convenient online submission

- Thorough peer review

- No space constraints or color figure charges

- Immediate publication on acceptance

- Inclusion in PubMed, CAS, Scopus and Google Scholar

- Research which is freely available for redistribution

Submit your manuscript at 